Neuropsychobiology 2017;75:200-210

DOI: $10.1159 / 000487484$
Received: April 4, 2017

Accepted after revision: January 30, 2018 Published online: April 5, 2018

\title{
Association of Polymorphisms of Serotonin Transporter (5HTTLPR) and 5-HT2C Receptor Genes with Criminal Behavior in Russian Criminal Offenders
}

\author{
Valentina A. Toshchakova ${ }^{a}$ Yalda Bakhtiari ${ }^{\mathrm{b}}$ Alexander V. Kulikov ${ }^{\mathrm{c}}$ \\ Sergey I. Gusev ${ }^{d}$ Marina V. Trofimova ${ }^{e}$ Olga Yu. Fedorenko ${ }^{a, f}$ \\ Ekaterina V. Mikhalitskaya ${ }^{a}$ Nina K. Popova ${ }^{c}$ Nikolay A. Bokhan ${ }^{a, g}$ \\ Johannes E. Hovens ${ }^{h}$ Anton J.M. Loonen ${ }^{b, i}$ Bob Wilffert ${ }^{b, j}$ \\ Svetlana A. Ivanova ${ }^{a, f}$
}

\begin{abstract}
${ }^{a}$ Mental Health Research Institute, Tomsk National Research Medical Center of the Russian Academy of Sciences, Tomsk, Russian Federation; ${ }^{b}$ Groningen Research Institute of Pharmacy, Unit of Pharmacotherapy, Epidemiology and Economics, University of Groningen, Groningen, The Netherlands; ' Institute of Cytology and Genetics, Siberian Branch of the Russian Academy of Sciences, Novosibirsk, Russian Federation; ${ }^{\mathrm{d}}$ Federal State Educational Institution of Higher Education "Kemerovo State Institute of Culture", Kemerovo, Russian Federation; "Psychology Department, Federal State Institution "Correctional Facility No. 43", Penitentiary Service of Russia for the Kemerovo Region, Kemerovo, Russian Federation; ${ }^{f}$ National Research Tomsk Polytechnic University, Tomsk, Russian Federation; ${ }^{9}$ National Research Tomsk State University, Tomsk, Russian Federation; ${ }^{\mathrm{h}}$ Faculty of Social Sciences, Erasmus University Rotterdam, Rotterdam, The Netherlands; 'GGZ Westelijk Noord-Brabant, Bergen op Zoom, The Netherlands; ${ }^{j}$ Department of Clinical Pharmacy and Pharmacology, University Medical Center Groningen, University of Groningen, Groningen, The Netherlands
\end{abstract}

\section{Keywords}

Aggression · Prisoners · Serotonin transporter $\cdot 5-\mathrm{HT} 2 \mathrm{C}$ receptor $\cdot$ Genotype

\begin{abstract}
Background: Human aggression is a heterogeneous behavior with biological, psychological, and social backgrounds. As the biological mechanisms that regulate aggression are components of both reward-seeking and adversity-fleeing behavior, these phenomena are difficult to disentangle into separate neurochemical processes. Nevertheless, evidence exists linking some forms of aggression to aberrant seroto-
\end{abstract}

nergic neurotransmission. We determined possible associations between 6 serotonergic neurotransmission-related gene variants and severe criminal offenses. Methods: Male Russian prisoners who were convicted for murder $(n=117)$ or theft ( $n=77$ ) were genotyped for variants of the serotonin transporter (5HTTLPR), tryptophan hydroxylase, tryptophan-2,3-dioxygenase, or type $2 \mathrm{C}(5-\mathrm{HT} 2 \mathrm{C})$ receptor genes and compared with general-population male controls ( $n=$ 161). Prisoners were psychologically phenotyped using the Buss-Durkee Hostility Inventory and the Beck Depression Inventory. Results: No differences were found between murderers and thieves either concerning genotypes or concerning psychological measures. Comparison of polymorphism

\begin{tabular}{|c|c|}
\hline KARGER & $\begin{array}{l}\text { (c) } 2018 \text { The Author(s) } \\
\text { Published by S. Karger AG, Basel }\end{array}$ \\
\hline $\begin{array}{l}\text { E-Mail karger@karger.com } \\
\text { www.karger.com/nps }\end{array}$ & $\begin{array}{l}\text { This article is licensed under the Creative Commons Attribution- } \\
\text { NonCommercial-NoDerivatives } 4.0 \text { International License (CC BY- } \\
\text { NC-ND) (http://www.karger.com/Services/OpenAccessLicense). } \\
\text { Usage and distribution for commercial purposes as well as any dis- } \\
\text { tribution of modified material requires written permission. }\end{array}$ \\
\hline
\end{tabular}

Prof. Anton J.M. Loonen, MD, PharmD, PhD

Groningen Research Institute of Pharmacy, Unit of Pharmacotherapy Epidemiology and Economics, University of Groningen

Antonius Deusinglaan 1, NL-9713AV Groningen (The Netherlands)

E-Mail a.j.m.loonen@rug.nl 
distribution between groups of prisoners and controls revealed highly significant associations of $5 \mathrm{HTTLPR}$ and 5-HTR2C (rs6318) gene polymorphisms with being convicted for criminal behavior. Conclusions: The lack of biological differences between the 2 groups of prisoners indicates that the studied 5HT-related genes do not differentiate between the types of crimes committed. @ 2018 The Author(s)

Published by S. Karger AG, Basel

\section{Introduction}

Behavior can be considered a mechanism where the brain manages input to create a specific output, which enables the organism to adapt to changed circumstances within its biosphere. In order to survive as an individual and a species, even humans' oldest animal ancestors must have been capable of obtaining food, water, warmth, territory, mating partners, and comfort or they must have been able to show a behavioral repertoire to escape from threat, the incapacity of having offspring, heat, cold, and other forms of distress [1]. Aggressive behavior is undoubtedly one of the most important conducts to accomplish these goals. However, as aggression is involved in both reward-seeking and adversity-fleeing behaviors, it necessarily represents a heterogeneous phenomenon. Throughout the animal kingdom, a similar set of aggressive behaviors can be distinguished which are employed to obtain these goals. However, in humans an extra capacity contributes to these ends. In humans, every sensory input and behavioral output can be replaced by abstract language symbols. The human mind can create a virtual world that is intermingled with the physical world, hence creating a unique human biosphere. Part of this virtual world is condensed in specific religious rules or country legislations. This complicates the study of the types and mechanisms of human aggressive behavior. Moreover, some of these kinds of offensive behaviors can be studied in animal models and others only in healthy human volunteers or patients.

Of all of the neurotransmitters, serotonin (5-hydroxytryptamine; 5-HT) has been especially associated with the occurrence of different types of aggression. The brain 5 -HT system is one of the most expansive neurotransmitter systems. 5-HT is synthesized from the essential amino acid L-tryptophan. Tryptophan hydroxylase 2 (TPH2) is the key and specific enzyme of 5-HT synthesis in the brain $[2,3]$. Synthesized $5-\mathrm{HT}$ is stored in synaptic vesicles and released into the synaptic cleft and it interacts with 14 types of postsynaptic 5-HT receptors [4]. The re-

SLC6A4 and HTR2C Polymorphisms and Criminal Behavior leased 5-HT is reuptaken from the synaptic cleft by the plasma membrane 5-HT transporter (5HTT) into presynaptic 5-HT neurons [5] where the neurotransmitter is either taken up by storage vesicles or oxidized to 5-hydroxyindoleacetic acid by monoamine oxidase A (MAO A) [6].

A vast body of experimental evidence has demonstrated a significant role of the genotype in the predisposition to aggressive behavior [7] and implicated brain 5-HT in the control of different kinds of animal aggressive behaviors [8-12]. The data concerning human aggression is more limited. Some clinical evidence associates impulsivity and aggression with central 5-HT activity [13-15]. However, the true relevance of a dysfunction of the 5-HT system for the mechanism of human aggression has been disputed [16]. The controversy may be due to $5-\mathrm{HT}$ playing a role in almost every integrative function of the central nervous system, such as mood, anxiety, stress, aggression, feeding, cognition, and sexual behavior [9]. The increase or decrease in 5-HT levels, therefore, has multiple, partly opposite, effects and the same is true for the acute and chronic effects of drugs that increase 5-HT levels [17]. This can be illustrated by regulatory role-playing by 5-HT neurotransmission within the adversity-fleeing as well as the reward-seeking systems [18]. Chronic administration of 5-HT level-increasing drugs results in downregulation of the sensitivity of 5-HT receptors $[18,19]$. Moreover, the activities of the reward-seeking and adversity-fleeing systems are reciprocally coupled to one another [18]. Aggressive behavior can be facilitated by both systems, with an emphasis on offensive and defensive aggression, respectively. Adversity-fleeing aggressive behavior is primarily related to anger/fear-type behavioral stress responses increasing the activity of the amygdaloidhippocampal activity [18]. Activation of the hippocampus and the amygdala as a reaction to anticipation of a monetary loss has been demonstrated in healthy human subjects [20]. Fibers of 5-HT neurons located at the dorsal raphe nucleus regulate acute adversity-avoidance behavior by stimulating 5-HT2C receptors (HTR2C) in the basolateral amygdala in rats $[21,22]$. These findings support the notion of a regulatory role of the amygdaloid-hippocampal complex inducing the activation of an adversityfleeing stress response by activation of 5-HT terminals coming from the dorsal raphe nucleus. Disinhibition of the amygdala by prefrontal dysfunction (organic or pharmacologically induced) and/or increased sensitivity of the amygdala due to genetic or environmental causes may result in an increased prevalence of serious aggressive incidents (including [para]suicide and homicide).

Neuropsychobiology 2017;75:200-210 DOI: $10.1159 / 000487484$ 
Ample evidence suggests that variations of genes modifying the functionality of 5-HT receptors, MAO A and 5-HT transporter (5HTT) may be relevant for impulsiveaggressive behavior and suicide [23-25], and associations between polymorphisms of these genes and impulsiveaggressive behavior and suicide have been shown $[23,24$, $26,27]$.

At least 17 molecules (TPH2, MAO A, 5HTT, and 14 serotonin receptors) regulate the serotonin synapse activity. Functional mutations in the genes coding these molecules are considered to be able to modulate 5-HT-related behavior. A common functional polymorphism, i.e., $-703 \mathrm{G}>\mathrm{T}$ in the human $\mathrm{TPH} 2$ gene, has been reported to be associated with numerous psychiatric disorders [28].

It has been shown that the $G$ allele and the G/G genotype of the common functional polymorphism $-1019 \mathrm{C}>\mathrm{G}$ (rs6295) in the human 5-HT1A receptor gene (HTR1A) could be associated with an increased risk of suicidal and impulsive behavior $[29,30]$.

Another receptor gene polymorphism that has been extensively investigated is the Cys23Ser variant (rs6318) of the 5-HT2C receptor gene (HTR2C) located on the extracellular $\mathrm{N}$-terminus of the receptor, potentially altering the protein's structure or stability by eliminating a disulfide bond [31]. The HTR2C gene is located on the X chromosome (Xq24 site), which means that males are hemizygous for cysteine $(\mathrm{G})$ or serine $(\mathrm{C})$ in the $23 \mathrm{rd}$ position [32].

Two common functional VNTR polymorphisms, 5HTTLPR and STin 2 in the promoter and the 2nd intron of the human 5HT transporter gene (SCL6A4), are known. The first includes 16 (long; L) or 14 (short; S) repeats of 22 bases [33, 34], while the second includes 12 (long) or 10 (short) repeats of 17 bases [35]. The short (S) allele reduces the SCL6A4 gene expression $[36,37]$. The long allele $(\mathrm{L})$ of the 5HTTLPR polymorphism is prevalent in Caucasians. There are numerous data associating the 5HTTLPR polymorphism with antisocial behavior, aggression and violence [38-40], alcohol [41, 42] and drug [43] addiction, and suicide [44], but also with positive characteristics such as creativity [45].

Tryptophan 2,3-dioxygenase (TDO2) catalyzes the first and rate-limiting step of the kynurenine pathway of the tryptophan metabolism and therefore affects serotonin synthesis [46].

The current study focuses on investigation the role 5-HT-related gene polymorphisms in human aggression. It was hypothesized that prisoners who had committed a murder carried polymorphisms of key genes encoding 5-HT neurotransmission different from criminal offend-
Table 1. Sociodemographic characteristics of the participants

\begin{tabular}{lcc}
\hline Variable & $\begin{array}{c}\text { Murderers } \\
(n=117)\end{array}$ & $\begin{array}{c}\text { Thieves } \\
(n=77)\end{array}$ \\
\hline Age, years & $38 \pm 0.99$ & $31 \pm 0.7$ \\
Age at first conviction, years & $17 \pm 0.3$ & $19 \pm 0.2$ \\
Convictions, $n$ & $3(2-3)$ & $3(3-4)$ \\
Sentence length, years & $13.6 \pm 0.6$ & $7 \pm 0.4$ \\
Time spent in prison, years & $5 \pm 0.3$ & $1.9 \pm 0.2$ \\
Marital status & $78(66.7)$ & $39(50.6)$ \\
$\quad$ Unmarried & $5(4.3)$ & $4(5.2)$ \\
$\quad$ Married & $25(21.4)$ & $22(28.6)$ \\
$\quad$ Divorced & $9(7.7)$ & $12(15.6)$ \\
Cohabitating & $48(41)$ & $33(42.9)$ \\
Education & $68(58.1)$ & $42(54.5)$ \\
$\quad$ Primary school & $1(0.9)$ & $2(2.6)$ \\
Secondary special education & $52(44.4)$ & $63(81.8)$ \\
$\quad$ Other &
\end{tabular}

Values are presented as means $\pm \mathrm{SD}$, medians (range), or numbers (\%).

ers who were convicted for theft. A psychological evaluation was used to assess aggression-related traits by applying the Buss-Durkee Hostility Inventory (BDHI) and depression was assessed with the Beck Depression Inventory (BDI) in order to reveal any association with genetic polymorphisms.

\section{Subjects and Methods}

Subjects

The work described in this article was carried out in accordance with the Code of Ethics of the World Medical Association (Declaration of Helsinki of 1975, revised in Fortaleza, Brazil, in 2013) for experiments involving humans. We examined a group of 194 criminal recidivists, consisting of 117 males convicted at least once for murder and 77 males who were only convicted for theft. During the examination all of the participants were serving a prison sentence in the Kemerovo State Correctional Facility (Kemerovo, Russia). One hundred sixty-one healthy male volunteers with no criminal record (aged $32.8 \pm 2.5$ years) comprised the control group. All of the participants were Caucasian, specifically Russian. Sociodemographic data is presented in Table 1.

\section{Ethical Committee}

Written informed consent was obtained from each participant after obtaining approval for this study from the Local Bioethics Committee of the Mental Health Research Institute. Participation or refusal to participate was without any consequences for their detention or position in prison, and this was explicitly explained to all of the participants as part of the informed consent. None of 
Table 2. Distribution of serotonin-related gene polymorphisms

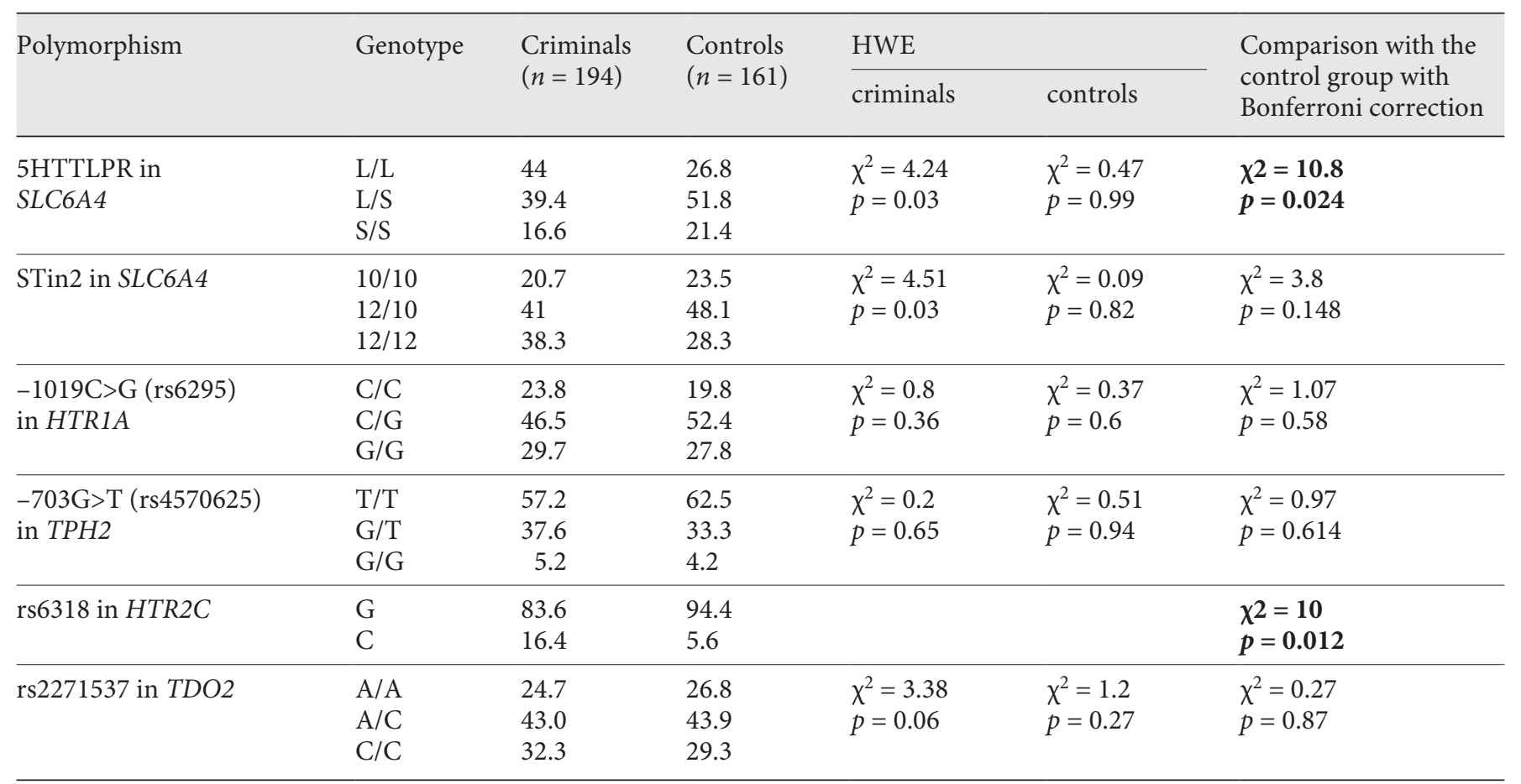

Values are presented as numbers unless otherwise stated. HWE, Hardy-Weinberg equilibrium. Bold is only used to highlight those cases with $p$ value $<0.05$ for the convenience of readers.

the participants had a compromised capacity/ability to consent; thus, consent from the next of kin was not necessary and not recommended by the local ethics committee. All findings were dealt with anonymously and were not reported back to the participants or staff.

\section{Phenotypic Measures}

Clinical and demographic data were extracted from the participants' files. Aggression-related traits were assessed using the BDHI, which includes 10 subscales (i.e., physical aggression [assault], indirect hostility, irritability, negativism, resentment, suspicion, verbal hostility, guilt, hostility index, and aggression index). Depression level was assessed with the BDI. BDHI and BDI self-assessments were supervised and checked by a clinical psychologist.

\section{Blood Sample Collection}

Blood samples were obtained from the participants via antecubital venipuncture. DNA was extracted from venous blood on a glass sorbent using a Medigen DNA extraction kit (Medigen, Russia) according to supplied protocol. The DNA concentration of the obtained samples ranged between 15 and $200 \mathrm{ng} / \mu \mathrm{L}$. Isolated DNA samples were kept at $-20^{\circ} \mathrm{C}$ until analysis.

\section{Genotyping}

Based on previously obtained data and literature evidence we selected the following polymorphisms: 5HTTLPR and VNTR-17
(STin2) in the 5HTT gene, $-703 \mathrm{G}>\mathrm{T}$ (rs4570625) in the TPH2 gene, $-1019 \mathrm{C}>\mathrm{G}$ (rs6295) in the HTR1A gene, rs6318 in the HTR2C gene, and rs2271537 in the TDO2 gene. During SNP selection we were guided by 2 rules: (1) the SNP must be functional and (2) the frequencies of both alleles must be near $50 \%$ (to provide the maximal number of each genotype). Hence, there existed a sufficient chance that such a polymorphism would be associated with a clinical difference when the corresponding protein was relevant for mediation of this effect.

Using suitable primers, 5HTTLPR and VNTR-17 (STin2) in the 5HTT gene were investigated via AFLP analysis [36, 45]. Polymorphisms of $703 \mathrm{G}>\mathrm{T}$ (TPH2 gene) and 1019C $>\mathrm{G}$ (HTR1A gene) were determined using an allele-specific PCR. To increase the specificity of the PCR, noncomplementary nucleotides were introduced in the $3^{\prime}$ position from the $3^{\prime}$-end of suitable allele-specific primers. Therefore, the PCR product was efficiently amplified only if the $3^{\prime}$-end nucleotide was complementary to genomic DNA. PCR was performed with a Verity ${ }^{\mathrm{TM}}$ thermocycler (Applied Biosystems, USA). PCR products were visualized by ethidium bromide staining in $2 \%$ agarose gel. The length of the amplicons was determined with a pBluescriptSK/MspI marker.

Genotyping of rs2271537 in the TDO2 gene and rs6318 in the HTR2C gene was performed with allele-specific real-time PCR using an Applied Biosystems-designed kit. Amplification was performed with a StepOnePlus cycler (Applied Biosystems), and the results were analyzed with cycler-supplied software. 
Statistical Analysis

Statistical analysis was performed using SPSS 20.0. The $\chi^{2}$-test was used for Hardy-Weinberg equilibrium and genotype distribution comparison. Bonferroni correction for multiple comparisons was used for the $\chi^{2}$-test of SNP frequencies. Since the primary outcome of this paper was to assess the difference in polymorphism frequencies between criminals and controls, calculation of Bonferroni correction value was performed using the formula $p<0.05 / \mathrm{m}$, where $m$ is the number of independent tests (in our case, $m=6$, as far as 6 genomic loci were analyzed). G*Power 3 software was employed for the power analysis of $\chi^{2}$-tested genotype distribution comparisons. The secondary outcome of this paper was to analyze associations of psychological data in criminals with different genotypes. Spearman's rank coefficient was used to evaluate the correlation between psychological scales. As scales of the BDHI were correlated to each other (data not shown), genetic associations with psychological data were assessed by MANOVA. The KruskalWallis test with following a Mann-Whitney test with Bonferroni correction was also applied.

\section{Results}

The power analysis showed that, in the case-control analysis, for 5HTTLPR in SLC6A4 we had sufficient power (i.e., 0.99) to detect a medium effect size of $w=0.34$, whereas for STin2 in SLC6A4 and for rs6318 in HTR2C we had sufficient power (i.e., 0.97 and 0.99 , respectively) to detect a small effect size of $w=0.21$ and $w=0.27$, respectively.

No association of $-703 \mathrm{G}>\mathrm{T},-1019 \mathrm{C}>\mathrm{G}$, STin2, and rs2271537 polymorphisms in the TPH2, HTR1A, SL$\mathrm{C} 6 \mathrm{~A} 4$, and TDO2 genes with criminal, aggressive (BDHI), or depressive (BDI) features was observed (Table 2).

At the same time, comparison of polymorphism distribution between the groups of prisoners and controls revealed an association of 5HTTLPR in the SLC6A4 gene $(\mathrm{OR}=1.55 ; 95 \%$ CI $1.15-2.10 ; p=0.004)$ and $\mathrm{rs} 6318$ in the HTR2C gene $(\mathrm{OR}=3.31 ; 95 \%$ CI $1.52-7.21 ; p=$ 0.0026 ) with being convicted for criminal behavior. An increase in the frequencies of the $\mathrm{L}$ allele and the $\mathrm{L} / \mathrm{L}$ genotype of 5HTTLPR and the C allele of the rs6318 polymorphism in the imprisoned criminals compared with the control group was revealed.

In order to gain a more detailed insight into the nature of the relationship between 5-HT-related gene polymorphisms and aggression-related psychological traits, an analysis of its associations was performed. Firstly, the relationship between BDHI and BDI scores and age, time spent in prison, and total sentence was tested using the Spearman correlation coefficient and it was not found to be significant $(p>0.05)$. Thus, age, time spent in prison, and total sentence were not used as covariates in all association analyses.
Tables 3 and 4 summarize the results of phenotypic data as a function of each SNP analyzed. Carriers of the rs6318 G genotype showed a higher score on the "negativism" scale of $\mathrm{BDHI}$ in comparison to more subjects in the group of criminals being $C$ carriers $(p=0.039)$. Furthermore, 5HTTLPR L/L carriers had a higher depression level compared to $S / S$ carriers $(p=0.027)$.

Post hoc tests were performed in order to compare groups of murderers and thieves. No difference was found in the genotype distributions of murderers and thieves or in depression levels $(\mathrm{p}=0.977)$. Interestingly, the only BDHI scale that showed a significant difference between murderers and thieves was "guilt" (Table 5).

\section{Discussion}

In this study, we examined a possible contribution of 6 functional genetic polymorphisms in 5 key genes encoding the brain 5-HT system, such as TPH2, SLC6A4, HTR1A, HTR2C, and TDO2, to a predisposition to severe criminal offensive behavior in criminal males from the Russian population. Two of these polymorphisms, i.e., 5HTTLPR in SLC6A4 and rs6318 in HTR2C genes, showed an association, reaching a significance level after Bonferroni adjustment.

\section{Limitations and Strengths of Our Study}

It was disappointing to find out that our expectations concerning possible differences between prisoners convicted for murder or theft were not confirmed. Hardly any differences were found with respect to psychological measures (BDHI and BDI). Another limitation is the probable differences between the sociological characteristics of prisoners and control subjects. When accepting the assumption that the current circumstances of certain social classes may increase the likelihood of being convicted of a felony due to living circumstances or a lack of juridical support, it is difficult to select comparators who are not at a similar risk of being imprisoned in the future. Finally, the sample size is rather limited for a genetic study.

Our study also has important strengths. As far as we know, this is the first genetic study of male Siberian criminal offenders. They were all Caucasian, which makes it a very interesting population to study. To our knowledge, there exist 5 studies of male criminal offenders: one Korean [47], one Czechian [48], one from the Southern USA [49], one Italian [50, 51], and one in a Finnish population [52]. Haeffel et al. [53] studied the relationship of poly- 
Table 3. BDHI subscale scores for different genotype carriers in prisoners

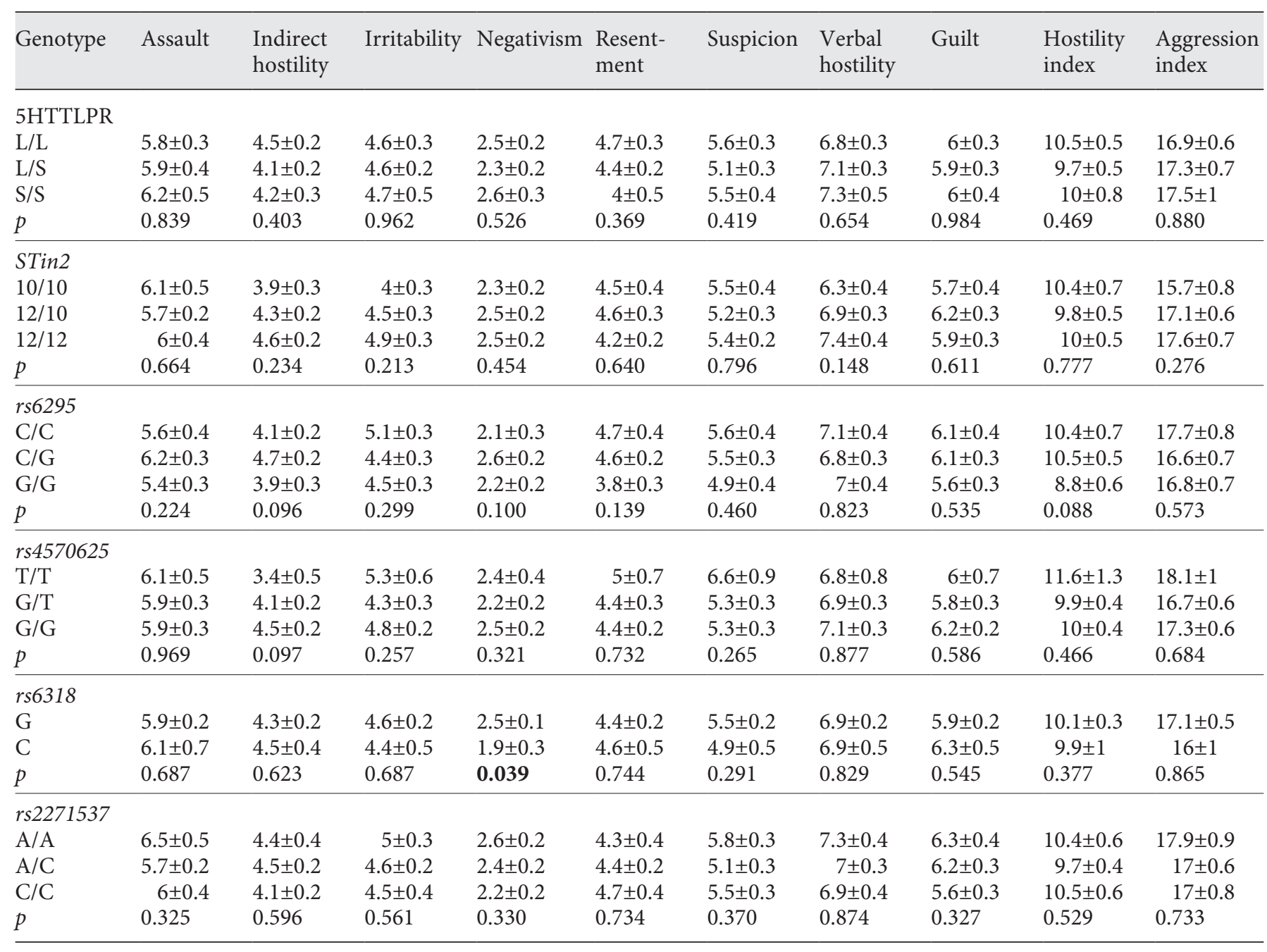

BDHI, Buss-Durkee Hostility Inventory. Bold is only used to highlight those cases with $p$ value $<0.05$ for the convenience of readers.

morphisms of the dopamine transporter gene and perceived maternal rejection at the onset of major depressive disorder in male adolescents $(n=176)$ recruited from a juvenile detention center in northern Russia. Retz et al. $[54,55]$ concentrated on the functional polymorphism of the 5 HTT promoter gene (5HTTLPR) and its impact on ADHD psychopathology in young German adult delinquents. Our imprisoned population is probably more severely disturbed than the persons studied by the other authors.

\section{Role of the 5-HT Transporter in Aggression}

Previous studies have revealed that the 5HTTLPR polymorphism may be related to aggression and antisocial behavior [39]. In their meta-analysis of association studies, those authors observed a moderate, positive association between the short $S$ allele of 5HTTLPR and antisocial behavior ( $\mathrm{OR}=1.41$; 95\% CI 1.26-1.59). However, a significant heterogeneity in the results of these studies was obvious, which is probably a good explanation for why we obtained dissimilar results. The human 5HTT gene (SLC6A4) contains a 22-bp repeat element (5HTTLPR) with a 44-bp insertion/deletion resulting in "long" and "short" (16- and 12-bp, respectively) variants $[39,56]$. The homozygous long (L/L) genotype results in an increased SLC6A4 transcriptional efficiency compared to the heterozygous (L/S) or homozygous short (S/S) genotypes [36, $39,56,57]$. The increase in the transcriptional efficiency 
Table 4. Depression level according to BDI scores in different genotype carriers in criminals

\begin{tabular}{|c|c|c|c|c|c|}
\hline 5HTTLPR in SLC6A4 & $\begin{array}{l}\mathrm{LL} \\
15.3 \pm 1\end{array}$ & $\begin{array}{l}\mathrm{LS} \\
14.7 \pm 1\end{array}$ & $\begin{array}{l}\text { SS } \\
10 \pm 1\end{array}$ & 0.035 & $\begin{array}{l}p(\mathrm{LL} / \mathrm{SS})=\mathbf{0 . 0 2 7} \\
p(\mathrm{LL} / \mathrm{LS})=0.129 \\
p(\mathrm{LS} / \mathrm{SS})=0.6\end{array}$ \\
\hline STin2 in SLC6A4 & $\begin{array}{l}10 / 10 \\
15 \pm 1.6\end{array}$ & $\begin{array}{l}12 / 10 \\
13.8 \pm 1\end{array}$ & $\begin{array}{l}12 / 12 \\
14.4 \pm 1\end{array}$ & 0.67 & \\
\hline$-703 \mathrm{G}>\mathrm{T}(\mathrm{rs} 4570625)$ in $\mathrm{TPH} 2$ & $\begin{array}{l}\mathrm{TT} \\
10.2 \pm 2.4\end{array}$ & $\begin{array}{l}\mathrm{GT} \\
14.4 \pm 1.3\end{array}$ & $\begin{array}{l}\mathrm{GG} \\
14.6 \pm 0.9\end{array}$ & 0.375 & \\
\hline rs6318 in HTR2C & $\begin{array}{l}\mathrm{G} \\
14.1 \pm 0.8\end{array}$ & & $\begin{array}{l}\mathrm{C} \\
16.9 \pm 2\end{array}$ & 0.217 & \\
\hline
\end{tabular}

Kruskal-Wallis test and Mann-Whitney test with Bonferroni correction. BDI, Beck Depression Inventory. Bold is only used to highlight those cases with $p$ value $<0.05$ for the convenience of readers.

of the L/L genotype appears to result in a lowered 5-HT concentration in the synaptic cleft and consequently less stimulation of excitatory HTR2C and other 5-HT receptors. It may be related to aggression and antisocial behavior [39], while the short allele is usually associated with such negative characteristics as violence $[38,40]$.

In our study, the L/L genotype of 5HTTLPR in the 5HTT gene in Caucasians was more frequent in both groups of criminals (murderers and thieves) than in the control males with no criminal records. Furthermore, 5HTTLPR L/L carriers showed a higher depression level in comparison with S/S carriers. This finding is in good agreement with the predicted antidepressant effect of the deficit of transporter functional activity in $S / S$ carriers. At the same time, other authors have associated the $\mathrm{S}$ allele with a predisposition to criminal behavior in the Han population [40]. The discrepancy between our data and those of Liao et al. [40] suggests an interaction between 5 HTT genes and some ethnic genetic factors.

\section{Role of the 5-HT2C Receptor in Aggression}

The HTR2C is mainly located in cortical areas, the hippocampus, the striatum, the septum, the thalamus, midbrain nuclei, the spinal cord, and, particularly, the choroid plexus [58]. The excitatory HTR2C has an inhibitory effect within the dorsal striatum (by activating fast spiking GABAergic interneurons) and probably activates the amygdaloid complex (by activating cortical pyramidal
Table 5. Comparison of BDHI subscale scores of murderers and thieves

\begin{tabular}{lccc}
\hline Scale & Murderers & Thieves & $p$ \\
\hline Assault & $6.1 \pm 0.3$ & $5.5 \pm 0.3$ & 0.100 \\
Indirect hostility & $4.3 \pm 0.18$ & $4.3 \pm 0.22$ & 0.931 \\
Irritability & $4.5 \pm 0.23$ & $4.9 \pm 0.25$ & 0.291 \\
Negativism & $2.4 \pm 0.1$ & $2.4 \pm 0.2$ & 0.811 \\
Resentment & $4.5 \pm 0.2$ & $4.4 \pm 0.2$ & 0.818 \\
Suspicion & $5.4 \pm 0.2$ & $5.4 \pm 0.3$ & 0.833 \\
Verbal hostility & $7.2 \pm 0.2$ & $6.8 \pm 0.3$ & 0.289 \\
Guilt & $5.7 \pm 0.2$ & $6.5 \pm 0.2$ & $\mathbf{0 . 0 2 3}$ \\
Hostility index & $10.3 \pm 0.4$ & $9.8 \pm 0.4$ & 0.426 \\
Aggression index & $17.2 \pm 0.5$ & $17.1 \pm 0.6$ & 0.915 \\
\hline
\end{tabular}

BDHI, Buss-Durkee Hostility Inventory. Bold is only used to highlight those cases with $p$ value $<0.05$ for the convenience of readers.

cells and nuclear GABAergic projection neurons). The dorsal extrapyramidal circuits with the caudate nucleus as a first relay station regulate the activity of the dorsolateral prefrontal cortex [32]. True activation of the basolateral part of the amygdaloid complex enhances the emotional flight/fight response [21, 22], while inverse activation of caudate HTR2C increases cognitive functioning and decreases defensive aggression. Clozapine, a very effective HTR2C inverse receptor agonist [59], reduced vi- 
olence and persistent aggression in patients with schizophrenia and other psychiatric disorders [60]. According to our data, carriers of the rs $6318 \mathrm{G}$ allele had lower scores on the "negativism" scale of the BDHI compared with the more frequent $\mathrm{C}$-allele carriers $(p=0.039)$. This could be related to the role of HTR2C within the "cognitive" extrapyramidal circuits which includes the caudate nucleus and targets the prefrontal cortex. Taken together with the fact that negativism reflects a propensity to opposition consisting of passive resistance or an active struggle against the established customs and laws [61], this result could be quite interesting.

Stimulation of HTR2C decreased dopaminergic stimulation of the dorsal striatum (caudate nucleus and putamen) and also increased prefrontal control due to direct activation of glutamatergic and monoaminergic neurons. Within ganglionic areas of the amygdaloid complex HTR2C were found on GABAergic neurons [62].

The HTR2C gene is located on the X chromosome, (Xq24 site), so males are hemizygous for cysteine (G) or serine $(C)$ in the $23 \mathrm{rd}$ position. However, the functional consequences of this polymorphism are debated. The Cys23Ser variant (rs6318) of the HTR2C gene polymorphism is located on the extracellular $\mathrm{N}$-terminus of the HTR2C protein, potentially altering the protein's structure or stability by eliminating a disulfide bond [31]. The findings of Lappalainen et al. [31] and Fentress et al. [63] do not support functional consequences of the C23S SNP in the HTR2C. However, Okada et al. [64] found that the Ser23 variant appears to be constitutively more active than Cys23. Jahnsen and Uhlèn [65] localized the C23S site within a cleavable signal peptide of the synthetized receptor protein. Cleaving of the signal peptide is important for translocation of the wild-type receptor to the plasma membrane, but they concluded that the site is probably absent from the mature HTR2C.

Our statistical analysis showed a higher frequency of C-carriers of the rs6318 polymorphism in the HTR2C gene in the group of criminals compared to the control probands. Interestingly, Banlaki et al. [66] studied 887 subjects ( $45.8 \%$ males and $54.2 \%$ females), all belonging to the middle socioeconomic class, and examined the possible contribution of 55 SNP to aggressive tendencies measured by the Buss-Perry Aggression Questionnaire. They did not observe any association between aggression and 3 variants of the HTR2C gene (including rs6318) [66]. However, those authors studied other psychological phenomena than we did in our study.

It should be kept in mind that positive associations between this polymorphism and disease states may be a consequence of linkage equilibrium with another SNP that is involved in the disease.

\section{Comparison of the Two Groups of Prisoners}

Based on the current opinion that direct physical aggression (murder) has a biological background which differs from that of indirect aggression (theft), we studied persons convicted of these 2 types of crimes separately. However, our results did not reveal any differences in polymorphism distribution. In terms of psychological data, only the "guilt" score in thieves seem to be higher than in murderers. This result, contradictory at first glance, may be explained from different points of view. Criminals, among whom this research was carried out, stayed a long time in the specific conditions of social isolation (1 year or more in a penitentiary facility with strict administrative and subcultural sanctions for acts of aggression). Criminal investigation, arrest, and imprisonment correct aggressive behavior to a great extent. Staying in the company of aggressive personalities also deters aggression, sublimating its manifestation to other forms. Therefore, the level of aggression in prison can significantly differ from the aggression level in the moment of crime commission. However, this does not explain the absence of genetic associations between the 2 groups, because these are primarily related to traits and not so much to states. An assumption exists that while the tendency of an individual toward criminal behavior can be determined by biological factors, the probability of highly aggressive destructive behavior in the form of homicide is defined by personal, social characteristics and individual predisposition, "the de-tabooing of evil" $[67,68]$. According to Moyer [69], heredity can determine the personal threshold beyond which the activation of specific neurophysiologic reactions associated with aggressive behavior begins. Mednick et al. [70] showed that adopted children of previously convicted biological parents had a higher risk of criminal behavior, but the types of crimes committed by adopted children and their biological parent did not correlate. Consequently, the type of crime seems not to be genetically determined, but some neurophysiological traits that can lead to antisocial behavior (e.g., impulsivity), may have a biological basis. In our study both murderers and thieves had numerous previous convictions, which indicates an antisocial pattern of behavior. The group of murderers was composed only of men who committed the crime impulsively, not premeditatedly. The group of thieves seems to have a higher "guilt" score, and this can indirectly reflect some personality traits more common in murderers, which can lead to a higher risk of an aggressive 
act in a form of homicide. Therefore, our data corroborate the suggestion that $5 \mathrm{HTT}$ and the HTR2C are implicated in the predisposition to criminal offensive behavior, but they could not be used as markers of a specific type of aggression. At the same time, the investigation should be supported by an evaluation of more neurophysiology-related characteristics, such as an impulsivity, personality traits, etc. Moreover, these psychological characteristics should be disentangled according to their relation to specific neurobiological functions such as medial prefrontal control over the amygdala, and the likelihood of initiation of an adversity-fleeing (defensive) response or initiation a reward-seeking (offensive) response.

Our study was limited to five 5-HT-related genes, while other important genes, such as those coding for the 5-HT2A receptor (HTR2A) and MAO A, were uninvestigated. At the same time, activation of HTR2A increases dopaminergic transmission within the ventral striatum (nucleus accumbens) and decreases prefrontal control due to the activation of inhibitory fast-spiking GABAergic interneurons. This combination would result in increased impulsivity. Within the cortical parts of the amygdaloid complex, HTR2A are present on glutamatergic pyramidal neurons and on inhibitory GABAergic interneurons and GABAergic projection neurons [62]. Hence, stimulation of HTR2A within the amygdaloid complex would have mixed effects. Banlaki et al. [66] showed an association between aggression and the rs7322347 polymorphism in the HTR2A gene. In our population, higher activity of the 5HTT resulting in less activation of HTR2A, is probably having quite unpredictable effects and the fact that our findings contrast with the median effect found in the meta-analysis of Ficks and Waldman [39] are very well in line with this.

Hereditary deficiency of MAO A produced aggressive and antisocial behavior in humans [27] and increased intermale aggression in mice [71]. Moreover, there is a common VNTR polymorphism affecting MAO A expression in vitro $[72,73]$. These functional polymorphisms in HTR2A and MAO A genes could be prospective targets for future studies of differentiation between murderers and thieves.

\section{Conclusion}

This study demonstrates the implication of the brain 5-HT system in the mechanisms of genetic predisposition to criminal antisocial behavior. An association of 5HTTLPR in 5-HT transporter (5HTT) and rs6318 in
5-HT2C receptor (HTR2C) genes with criminality, aggression-related traits, and depression was found. This result contributes to the theory that 5HTT and HTR2C are involved in biological mechanisms of antisocial criminal behavior. However, the lack of biological differences between the 2 groups of prisoners (murderers and thieves) indicates that these members of the 5-HT family do not differentiate between the type and the severity of the crime committed. In the future, other specific elements in the brain 5-HT system (e.g., MAO A and the 5-HT2A receptor) as well as offensive versus defensive backgrounds of aggressive behavior should be considered when studying the genetics of criminal behavior.

\section{Acknowledgement}

This study was originally performed in the frame of Basis Research Project No. 0324-2015-0004 and continued within the framework of Tomsk Polytechnic University Competitiveness Enhancement Program.

\section{Disclosure Statement}

None.

\section{Funding Sources}

None.

\section{Author Contributions}

S.A.I. conceived, designed, coordinated, and supervised this study. V.A.T. and S.A.I. wrote the study protocol after reviewing the literature. V.A.T. monitored this study and collected clinical data and biological samples. V.A.T., Y.B., A.V.K., and E.V.M. genotyped the samples and recorded all of the data in an Excel data base. S.I.G. and M.V.T. did the clinical work. N.A.B. supervised and discussed the clinical work. O.Yu.F., N.K.P., and S.A.I. supervised the technical work. V.A.T. and N.K.P. designed and performed the statistical analysis. Y.B., V.A.T., and A.J.M.L. wrote this paper. S.A.I., V.A.T., J.E.H., O.Yu.F., and B.W. commented on this paper. All of the authors read this paper and agree with its content. 


\section{References}

1 Loonen AJM, Ivanova SA: Circuits regulating pleasure and happiness: the evolution of reward-seeking and misery-fleeing behavioral mechanisms in vertebrates. Front Neurosci 2015;9:394.

2 Walther DJ, Bader M: A unique central tryptophan hydroxylase isoform. Biochem Pharmacol 2003;66:1673-1680.

3 Walther DJ, Peter JU, Bashammakh S, Hortnagl H, Voits M, Fink H, Bader M: Synthesis of serotonin by a second tryptophan hydroxylase isoform. Science 2003;299:376.

4 Barnes NM, Sharp T: A review of central 5-HT receptors and their function. Neuropharmacology 1999;38:1083-1152.

5 Barker E, Blakey R: Norepinephrine and serotonin transporters: molecular targets of antidepressant drugs; in Bloom E, Kupfer N (eds) Psychopharmacology: the Fourth Generation of Progress. New York, Raven Press, 1995, pp 321-333.

6 Shih JC, Thompson RF: Monoamine oxidase in neuropsychiatry and behavior. Am J Hum Genet 1999;65:593-598.

7 Popova NK, Nikulina EM, Kulikov AV: Genetic analysis of different kinds of aggressive behavior. Behav Genet 1993;23:491-497.

8 Kulikov AV, Osipova DV, Naumenko VS, Popova NK: Association between Tph2 gene polymorphism, brain tryptophan hydroxylase activity and aggressiveness in mouse strains. Genes Brain Behav 2005;4:482-485.

9 Olivier B: Serotonin: a never-ending story. Eur J Pharmacol 2015;753:2-18.

10 Olivier B, Mos J, van Oorschot R, Hen R: Serotonin receptors and animal models of aggressive behavior. Pharmacopsychiatry 1995 28:80-90.

11 Popova NK: From genes to aggressive behavior: the role of serotonergic system. Bioessays 2006;28:495-503.

12 Popova NK, Kulikov AV, Nikulina EM, Kozlachkova EY, Maslova GB: Serotonin metabolism and 5-HT receptors in Norway rats selected for low aggressiveness to man. Aggr Behav 1991;17:207-213.

13 Rosell DR, Siever LJ: The neurobiology of aggression and violence. CNS Spectr 2015;20: 254-279.

14 Tuinier S, Verhoeven WM: Neurobiology or aggression and impulsivity. Acta Neuropsychiatr 1999;11:5-10.

15 Yanowitch R, Coccaro EF: The neurochemistry of human aggression. Adv Genet 2011;75 151-169.

16 Duke AA, Bègue L, Bell R, Eisenlohr-Moul T: Revisiting the serotonin-aggression relation in humans: a meta-analysis. Psychol Bull 2013;139:1148-1172.

17 Carrillo M, Ricci LA, Coppersmith GA, Melloni RH Jr: The effect of increased serotonergic neurotransmission on aggression: a critical meta-analytical review of preclinical studies. Psychopharmacology (Berl) 2009;205 349-368.
18 Loonen AJM, Ivanova SA: Circuits regulating pleasure and happiness in major depression. Med Hypotheses 2016;87:14-21.

19 Loonen AJM, Ivanova SA: Circuits regulating pleasure and happiness: mechanisms of depression. Front Hum Neurosci 2016;10:571.

20 Hahn T, Dresler T, Plichta MM, Ehlis AC, Ernst LH, Markulin F, Polak T, Blaimer M, Deckert J, Lesch KP, Jakob PM, Fallgatter AJ: Functional amygdala-hippocampus connectivity during anticipation of aversive events is associated with Gray's trait "sensitivity to punishment.” Biol Psychiatry 2010;68:459464.

21 Christianson JP, Greenwood BN: Stress-protective neural circuits: not all roads lead through the prefrontal cortex. Stress 2014;17: $1-12$.

22 Zangrossi H Jr, Graeff FG: Serotonin in anxiety and panic: contributions of the elevated T-maze. Neurosci Biobehav Rev 2014;46: 397-406.

23 Bortolato M, Pivac N, Muck Seler D, Nikolac Perkovic M, Pessia M, Di Giovanni G: The role of the serotonergic system at the interface of aggression and suicide. Neuroscience 2013; 236:160-185.

24 Pavlov KA, Chistiakov DA, Chekhonin VP: Genetic determinants of aggression and impulsivity in humans. J Appl Genet 2012;53: 61-82.

25 Popova NK: From genes to aggressive behavior: the role of serotonergic system. Bioessays 2006;28:495-503.

26 Antypa N, Serretti A, Rujescu D: Serotonergic genes and suicide: a systematic review. Eur Neuropsychopharmacol 2013;23:1125-1142.

27 Brunner HG, Nelen M, Breakefield XO, Ropers $\mathrm{HH}$, van Oost BA: Abnormal behavior associated with a point mutation in the structural gene for monoamine oxidase A. Science 1993;262:578-580.

28 Chen GL, Vallender EJ, Miller GM: Functional characterization of the human $\mathrm{TPH} 25^{\prime}$ regulatory region: untranslated region and polymorphisms modulate gene expression in vitro. Hum Genet 2008;122:645-657.

29 Benko A, Lazary J, Molnar E, Gonda X, Tothfalusi L, Pap D, Mirnics Z, Kurimay T, Chase D, Juhasz G, Anderson IM, Deakin JF, Bagdy G: Significant association between the $C(-1019) \mathrm{G}$ functional polymorphism of the HTR1A gene and impulsivity. Am J Med Genet B Neuropsychiatr Genet 2010;153B: 592-629.

30 Sukhodolskaya EM, Vasilyev VA, Shibalev DV, Shcherbakova OI, Kulikov AM, Lazebny OE, Karelin DV, Butovskaya ML, Ryskov AP: Comparative analysis of polymorphisms of the serotonin receptor genes HTR1A, HTR2A, and HTR1B in Hadza and Datoga males. Genetika 2015;51:1308-1314

31 Lappalainen J, Zhang L, Dean M, Oz M, Ozaki N, Yu DH, Virkkunen M, Weight F, Linnoila M, Goldman D: Identification, expres- sion, and pharmacology of a Cys23-Ser23 substitution in the human 5 -HT2c receptor gene (HTR2C). Genomics 1995;27:274-279.

32 Loonen AJM, Ivanova SA: Role of 5-HT2C receptors in dyskinesia. Int J Pharm Pharm Sci 2016;8:5-10.

33 Lesch KP, Wolozin BL, Estler HC, Murphy DL, Riederer P: Isolation of a cDNA encoding the human brain serotonin transporter. J Neural Transm Gen Sect 1993;91:67-72.

34 Lesch KP, Balling U, Gross J, Strauss K, Wolozin BL, Murphy DL, Riederer P: Organization of the human serotonin transporter gene. J Neural Transm Gen Sect 1994;95:157162.

35 Ogilvie AD, Battersby S, Bubb VJ, Fink G, Harmar AJ, Goodwim GM, Smith CA: Polymorphism in serotonin transporter gene associated with susceptibility to major depression. Lancet 1996;347:731-733.

36 Lesch KP, Bengel D, Heils A, Sabol SZ, Greenberg BD, Petri S, Benjamin J, Müller CR, Hamer DH, Murphy DL: Association of anxiety-related traits with a polymorphism in the serotonin transporter gene regulatory region. Science 1996;274:1527-1531.

37 Fiskerstrand CE, Lovejoy EA, Quinn JP: An intronic polymorphic domain often associated with susceptibility to affective disorders has allele dependent differential enhancer activity in embryonic stem cells. FEBS Lett 1999; 458:171-174.

38 Beitchman JH, Baldassarra L, Mik H, De Luca V, King N, Bender D, Ehtesham S, Kennedy JL: Serotonin transporter polymorphisms and persistent, pervasive childhood aggression. Am J Psychiatry 2006; 163:1103-1105.

39 Ficks CA, Waldman ID: Candidate genes for aggression and antisocial behavior: a metaanalysis of association studies of the 5HTTLPR and MAOA-uVNTR. Behav Genet 2014; 44:427-444.

40 Liao D-L, Hong Ch-J, Shih H-L, Tsai S-J: Possible association between serotonin transporter promoter region polymorphism and extremely violent crime in Chinese males. Neuropsychobiology 2004;50:284-287.

41 Feinn R, Nellissery M, Kranzler HR: Metaanalysis of the association of a functional serotonin transporter promoter polymorphism with alcohol dependence. Am J Med Genet B Neuropsychiatr Genet 2005;133B:79-84.

42 Herman AI, Philbeck JW, Vasilopoulos NL Depetrillo PB: Serotonin transporter promoter polymorphism and differences in alcohol consumption behavior in a college student population. Alcohol Alcohol 2003;38:446449

43 Gerra G, Carofano L, Santoro G, Bosari S, Pellegrini C, Zaimovic A, Moi G, Bussandri M, Moi A, Brambilla F, Donnini C: Association between low-activity serotonin transporter genotype and heroin dependence: behavioral and personality correlates. Am J Med Genet B (Neuropsychiatr Genet) 2004;126B:37-42. 
44 Gorwood P, Batel P, Ades J, Hamon M, Boni C: Serotonin transporter gene polymorphisms, alcoholism, and suicidal behavior. Biol Psychiatry 2000;48:259-264.

45 Volf NV, Kulikov AV, Bortsov CU, Popova NK: Association of verbal and figural creative achievement with polymorphism in the human serotonin transporter gene. Neurosci Lett 2009;463:154-157.

46 Maes M, Leonard BE, Myint AM, Kubera M, Verkerk R: The new "5-HT" hypothesis of depression: cell-mediated immune activation induces indoleamine 2,3-dioxygenase, which leads to lower plasma tryptophan and an increased synthesis of detrimental tryptophan catabolites (TRYCATs), both of which contribute to the onset of depression. Prog Neuropsychopharmacol Biol Psychiatry 2011;35: 702-721.

47 Lee JH, Kim HT, Hyun DS: Possible association between serotonin transporter promoter region polymorphism and impulsivity in Koreans. Psychiatry Res 2003;118:19-24.

48 Vevera J, Stopkova R, Bes M, Albrecht T, Papezova H, Zukov I, Raboch J, Stopka P: COMT polymorphisms in impulsively violent offenders with antisocial personality disorder. Neuro Endocrinol Lett 2009;30:753756.

49 Armstrong TA, Boutwell BB, Flores S, Symonds M, Keller S, Gangitano DA: Monoamine oxidase A genotype, childhood adversity, and criminal behavior in an incarcerated sample. Psychiatr Genet 2014;24:164-171.

50 Gorodetsky E, Bevilacqua L, Carli V, Sarchiapone M, Roy A, Goldman D, Enoch M-A: The interactive effect of MAOA-LPR genotype and childhood physical neglect on aggressive behaviors in Italian male prisoners. Genes Brain Behav 2014;13:543-549.

51 Gorodetsky E, Carli V, Sarchiapone M, Roy A, Goldman D, Enoch MA: Predictors for selfdirected aggression in Italian prisoners include externalizing behaviors, childhood trauma and the serotonin transporter gene polymorphism 5HTTLPR. Genes Brain Behav 2016;15:465-473.

52 Tiihonen J, Rautiainen MR, Ollila HM, RepoTiihonen E, Virkkunen M, Palotie A, Pietiläinen $\mathrm{O}$, Kristiansson $\mathrm{K}$, Joukamaa $\mathrm{M}$, Lauerma H, Saarela J, Tyni S, Vartiainen H,
Paananen J, Goldman D, Paunio T: Genetic background of extreme violent behavior. Mol Psychiatry 2015;20:786-792.

53 Haeffel GJ, Getchell M, Koposov RA, Yrigollen CM, Deyoung CG, Klinteberg BA, Oreland L, Ruchkin VV, Grigorenko EL: Association between polymorphisms in the dopamine transporter gene and depression: evidence for a gene-environment interaction in a sample of juvenile detainees. Psychol Sci 2008; 19:62-69.

54 Retz W, Retz-Junginger P, Supprian T, Thome J, Rösler M: Association of serotonin transporter promoter gene polymorphism with violence: relation with personality disorders, impulsivity, and childhood ADHD psychopathology. Behav Sci Law 2004;22:415425.

55 Retz W, Freitag CM, Retz-Junginger P, Wenzler D, Schneider M, Kissling C, Thome J, Rösler M: A functional serotonin transporter promoter gene polymorphism increases ADHD symptoms in delinquents: interaction with adverse childhood environment. Psychiatry Res 2008;158:123-131.

56 Heils A, Teufel A, Petri S, Stöber G, Riederer P, Bengel D, Lesch KP: Allelic variation of human serotonin transporter gene expression. J Neurochem 1996;66:2621-2624.

57 Cadoret RJ, Langbehn D, Caspers K, Troughton EP, Yucuis R, Sandhu HK, Philibert R: Associations of the serotonin transporter promoter polymorphism with aggressivity, attention deficit, and conduct disorder in an adoptee population. Compr Psychiatry 2003; 44:88-101.

58 Leysen JE: 5-HT2 receptors. Curr Drug Targets CNS Neurol Disord 2004;3:11-26.

59 Aloyo VJ, Berg KA, Spampinato U, Clarke WP, Harvey JA: Current status of inverse agonism at serotonin2A (5-HT2A) and 5-HT2C receptors. Pharmacol Ther 2009;121:160173.

60 Frogley C, Taylor D, Dickens G, Picchioni M: A systematic review of the evidence of clozapine's anti-aggressive effects. Int J Neuropsychopharmacol 2012;15:1351-1371.

61 Dermanova IB: Emotional Development Diagnostics: Diagnostics of Aggression (BussDurkee Inventory). St Petersburg, SPB, 2002, pp 80-84.
62 Bombardi C: Neuronal localization of the 5-HT2 receptor family in the amygdaloid complex. Front Pharmacol 2014;5:68.

63 Fentress HM, Grinde E, Mazurkiewicz JE, Backstrom JR, Herrick-Davis K, SandersBush E: Pharmacological properties of the Cys23Ser single nucleotide polymorphism in human 5-HT2C receptor isoforms. Pharmacogenomics J 2005;5:244-254.

64 Okada M, Northup JK, Ozaki N, Russell JT, Linnoila M, Goldman D: Modification of human 5-HT(2C) receptor function by Cys23Ser, an abundant, naturally occurring amino-acid substitution. Mol Psychiatry 2004;9:55-64.

65 Jahnsen JA, Uhlén S: The N-terminal region of the human $5-\mathrm{HT}_{2} \mathrm{C}$ receptor has as a cleavable signal peptide. Eur J Pharmacol 2012; 684:44-50.

66 Banlaki Z, Elek Z, Nanasi T, Szekely A, Nemoda Z, Sasvari-Szekely M, Ronai Z: Polymorphism in the serotonin receptor 2a (HTR2A) gene as possible predisposal factor for aggressive traits. PLoS One 2015;10:e0117792.

67 Leontiev DA: From social to personal values: sociogenesis and phenomenology of value system-mediated regulation of activity (article one). The Moscow University Herald. Series 14. Psychology 1996;8:35-44.

68 Antonyan YM, Guldan VV: Criminal Psychopathology. Moscow, Nauka, 1991, p 248.

69 Moyer KE: Biological substrates of aggression and implications for control; in Brain T, Benton D (eds): The Biology of Aggression. Rockville, Sythoff \& Noordhoff, 1981, pp 47-67.

70 Mednick SA, Gabrielli WF, Hutchings B: In reply: criminality and adoption. Science 1985; 227:984-989.

71 Popova NK, Skrinskaya YA, Amstislavskaya TG, Vishnivetskaya GB, Seif I, de Meier E: Behavioral characteristics of mice with genetic knockout of monoamine oxidase type A. Neurosci Behav Physiol 2001;31:597-602.

72 Denney RM, Koch H, Craig IW: Association between monoamine oxidase A activity in human male skin fibroblasts and genotype of the MAOA promoter-associated variable number tandem repeat. Hum Genet 1999;105: 542-551.

73 Sabol SZ, Hu S, Hamer D: A functional polymorphism in the monoamine oxidase A gene promoter. Hum Genet 1998;103:273-279. 